\title{
Crude ethanol extract from babassu (Orbignya speciosa): cytotoxicity on tumoral and non-tumoral cell lines
}

\author{
MAGDALENA N. RENNÓ ${ }^{1}$, GLEYCE M. BARBOSA ${ }^{1}$, PATRICIA ZANCAN ${ }^{2}$, \\ VENICIO F. VEIGA ${ }^{3}$, CELUTA S. ALVIANO ${ }^{4}$, MAURO SOLA-PENNA ${ }^{2}$, \\ FÁBIO S. MENEZES $^{5}$ and CARLA HOLANDINO ${ }^{1}$ \\ ${ }^{1}$ Laboratório Multidisciplinar de Ciências Farmacêuticas, Departamento de Medicamentos, Faculdade de Farmácia \\ Centro de Ciências da Saúde, UFRJ, Rua Professor Rodolfo Rocco s/n, Bloco B, sub-solo, sala 11 \\ Ilha do Fundão, 21941-590 Rio de Janeiro, RJ, Brasil \\ ${ }^{2}$ Laboratório de Enzimologia e Controle do Metabolismo (LabECoM), Departamento de Fármacos, Faculdade de Farmácia \\ Centro de Ciências da Saúde, UFRJ, Rua Professor Rodolfo Rocco s/n, Bloco B, sub-solo, sala 27 \\ Ilha do Fundão, 21941-590 Rio de Janeiro, RJ, Brasil \\ ${ }^{3}$ Instituto de Microbiologia Professor Paulo de Góes, Centro de Ciências da Saúde, UFRJ \\ Rua Professor Rodolfo Rocco s/n, Bloco I, sub-solo, sala 27, Ilha do Fundão, 21941-590 Rio de Janeiro, RJ, Brasil \\ ${ }^{4}$ Instituto de Microbiologia Professor Paulo de Góes, Centro de Ciências da Saúde, UFRJ \\ Rua Professor Rodolfo Rocco s/n, Bloco I, $1^{\circ}$ andar, sala 50, Ilha do Fundão, 21941-590, Rio de Janeiro, RJ, Brasil \\ ${ }^{5}$ School of Pharmacy and Pharmaceutical Sciences, Trinity College, Dublin, 23, Westland Row, Dublin 2, Ireland \\ Manuscript received on August 14, 2007; accepted for publication on March 27, 2008; \\ presented by SERGIO VERJOVSKI-ALMEIDA
}

\begin{abstract}
Plant-derived substances have been considered as important sources of drugs, including antineoplasic agents. Babassu mesocarp is popularly used in Brazil as a food additive, and in popular medicine against several conditions, such as inflammations, menstrual pains and leukaemia. From babassu Orbignya speciosa (Mart.) Barb. Rodr. [Arecaceae (Palmae)] epicarp/mesocarp, an ethanol extract was prepared and named OSEME, which was tested on the viability, morphology and metabolism of several cell lines, such as the leukaemic cell lines, HL-60, K562 and the latter multidrugresistant counterpart K562-Lucena 1, the human breast cancer cell line MCF-7, the mouse fibroblast cell line 3T3-L1 and fresh human lymphocytes. OSEME promoted a dose-dependent decrease on the viability of all cells. This effect was much more pronounced on the tumoral cell lines than on non-tumoral cells, a phenomenon revealed by the dose of OSEME which promotes half of maximal effect $\left(I D_{50}\right)$. The decrease on viability was followed by shrinkage of cells, alteration on their morphology, and a markedly nuclear condensation. Curiously, stimulation of 6-phosphofructokinase activity (6.6-times) was observed on HL-60 cells, treated with OSEME, when compared to control treated with ethanol (vehicle). These results support evidences to suggest OSEME as a promising source of novel antineoplasic agents.
\end{abstract}

Key words: antitumoral agents, ethanol extract, Orbignya speciosa.

\section{INTRODUCTION}

Babassu (Orbignya martiana, O. oleifera or O. speciosa) is a native palm tree from the North, Northeast and Central regions of Brazil, occurring mainly in the Maranhão, Piaui, Tocantins and Goias States in extensive

Correspondence to: Dra. Carla Holandino

E-mail: cholandino@yahoo.com forests (Emmerich and Luengo 1996). Traditionally, the babassu mesocarp has been used for the treatment of several conditions including inflammations of the uterus and ovarium, treatment of constipation, colitis, obesity, and leukaemias, among other tumors (Silva and Parente 2001). 
The vast diversity of the Brazilian flora stimulates the exploitation of plant extracts with medical and biological activities. In this regard, studies of plant compounds with antioxidant activity has attracted great interest in the last years, due to the fact that free radicals have been clearly associated to pathological process, including cancer. Some authors have associated the prevention of cancer with the ingestion of plant extracts enriched in natural antioxidants (for a review see Ferguson and Philpott 2007). We have recently described that babassu extracts present antioxidant activity acting as free radical scavengers, evaluated by means of reduction of 1,1-diphenyl-2-picrylhydrazyl (DPPH) and protecting yeast cells from lethal oxidative stress (Silva et al. 2005). Moreover, other therapeutic properties of babassu have been reported, such as anti-inflammatory (Silva and Parente 2001), cicatrizant (Martins et al. 2006), gastric healing (Batista et al. 2006), antithyroid (Gaitan et al. 1994), anti-thrombotic (Azevedo et al. 2007) and anti-microbial (Caetano et al. 2002).

The aim of the present study is to evaluate the effects of babassu extract on the viability, morphology and metabolism of leukaemic cell lines in culture, as well as on other tumor cells, non-tumor immortalized cell lines and freshly isolated human lymphocytes. Here we show a cytotoxic effect of babassu extract, which is indicative of a possible usage of babassu as a source of antineoplasic compounds with low damage to normal cells.

\section{MATERIALS AND METHODS}

\section{Plant Material}

The babassu (Orbignya speciosa (Mart.) Barb. Rodr.) fruits were collected in December 2002, in the Piauí State, Brazil. A voucher specimen was deposited in the Graziella Barroso Herbarium (Federal University of Piauí), under the number TEPB 18985.

\section{SAMPLE PREPARATION}

The epicarp/mesocarp (at least 1200g) from the fruits was dried, powdered and submitted to successive extraction by maceration with $96 \%$ ethanol, at room temperature (Silva et al. 2005). All the extract was filtered through filter paper and then the crude ethanol extract of the epicarp/mesocarp was evaporated to dryness in a rotatory evaporator, with average yield from $3 \%$ of the starting material dry weight. After drying, the extract was suspended in ethanol. The ethanol extract of epicarp/mesocarp (OSEME) was further sterilized by filtration $(0.22 \mu \mathrm{m})$, for biological assays.

\section{Cell Culture}

The erythroleukaemic cell line K562 and its multidrugresistant (MDR) counterpart, K562-Lucena 1 and lymphocytes cells were kindly donated by Dr. Vivian M. Rumjanek (Instituto de Bioquímica Médica, UFRJ, Rio de Janeiro, Brazil). The human promyelocitic leukaemic cell line HL-60, 3T3-L1 mouse fibroblasts and MCF-7 cells (mammary duct carcinoma cell line) were obtained from Cell Bank of Hospital Universitário Clementino Fraga Filho, UFRJ, Brazil. Cells were grown at $37^{\circ} \mathrm{C}$ in $25 \mathrm{~cm}^{2}$ culture flasks containing Dulbecco's modified Eagle's medium (D-MEM) supplemented with $10 \%$ of fetal bovine serum (FBS-Gibco, Invitrogen, USA), 1\% PSA $(10,000 \mathrm{UI} / \mathrm{mL}$ penicillin G sodium, 10,000 g/mL streptomycin sulfate and $25 \mu \mathrm{g} / \mathrm{mL}$ amphotericin $\mathrm{B}$, as Fungizone $\left.{ }^{\circledR}\right)$. D-MEM medium was previously supplemented with $3 \mathrm{~g} / \mathrm{L} N$-(2-hydroxyethyl)-piperazine- $N$ '(2-ethanesulfonic acid) (HEPES), $0.3 \mathrm{~g} / \mathrm{L}$ L-glutamine and $0.2 \mathrm{~g} / \mathrm{L} \mathrm{NaHCO}_{3}$ ( $\mathrm{pH} 7.4$ ), as previously described (Freshney 1994). K562-Lucena 1 cells were maintained in the presence of $60 \mathrm{nM}$ vincristine (Maia et al. 1996), while the medium used for cultivation of MCF-7 was also supplemented with $5 \mu \mathrm{g} / \mathrm{mL}$ insulin.

\section{FRESH HUMAN LyMPHOCYTES PREPARATION}

Peripheral blood mononuclear (lymphocytes) cells were collected from fresh heparinized blood of health volunteers (18-30 years old) by venopuncture and separated by density gradient centrifugation $\left(\right.$ Ficoll $\left.^{\circledR}\right)$. In $50 \mathrm{~mL}$ conical tubes, $20 \mathrm{~mL}$ of blood was layered over $15 \mathrm{~mL}$ of Ficoll ${ }^{\circledR}$, followed by centrifugation at $1800 \mathrm{rpm}$ for $30 \mathrm{~min}$ at room temperature. Buffy coats and serum were collected in phosphate-buffered saline and centrifuged at $1200 \mathrm{rpm}$ for $7 \mathrm{~min}$ at room temperature (Baruque et al. 2005). Supernatants were discarded; cells were washed two times in $50 \mathrm{~mL}$ of phosphatebuffered saline, and re-suspended in the same culture medium described above. 


\section{CYTOTOXICITY AsSAYS}

\section{Non-adherent cells}

For cytotoxicity assays, approximately $5 \times 10^{5}$ leukaemia cells were suspended in D-MEM/FBS and plated into the wells of 24-well culture plates. They were treated with different concentrations $(150,300,600,1200,1500$ and $2000 \mu \mathrm{g} / \mathrm{mL}$ ) of the OSEME or $1.2 \%$ ethanol (used as OSEME vehicle). The cells were incubated at $37^{\circ} \mathrm{C}$ and viability was evaluated by permeability to trypan blue (Patterson 1979), after 1, 4, 8 and 24 hours. The effects of the OSEME on inhibition of cell proliferation were calculated by comparing extract-treated cells with untreated cells. The number of viable cells in the different systems was determined as previously described (Holandino et al. 2001), and the suspensions containing similar cell numbers cultivated in 24 well plates for 24 hours as described above. Aliquots of $25 \mu \mathrm{l}$ of the cell culture were then mixed with $25 \mu$ l of trypan blue and the total number of cells determined in a Neubauer chamber. Non-viable cells were divided in trypan blue-stained cells that retained their shape and lyzed leukaemic cells (Veiga et al. 2005). Effects of the OSEME on lymphocytes were evaluated after a $24 \mathrm{~h}$ treatment, followed by staining with trypan blue. The cells were plated in 24 well culture plates in D-MEM/FBS, and treated with 300, 600, $1200 \mu \mathrm{g} / \mathrm{mL}$ of the OSEME or $1.20 \%$ ethanol (used as OSEME vehicle) at $37^{\circ} \mathrm{C}$.

\section{Adherent cells}

The confluent cell lines MCF-7 and 3T3-L1 were plated into the wells of 24-well plates in the presence of OSEME $(300,600$ and $1200 \mu \mathrm{g} / \mathrm{mL})$ or control, $1.20 \%$ ethanol, and incubated for 24 hours at $37^{\circ} \mathrm{C}$. The supernatant was then removed and the cells were washed twice with PBS, followed by trypsinization and suspension in $1 \mathrm{~mL}$ DMEM. Cell viability was evaluated as described above.

\section{RADIOASSAY FOR 6-PHOSPHOFRUCTO-1-KINASE}

\section{ACTIVITY}

The HL-60 cells were cultivated in presence of $300 \mu \mathrm{g} /$ mL OSEME, $1.20 \%$ ethanol (vehicle control) or in medium alone for 24 hours at $37^{\circ} \mathrm{C}$. 6-Phosphofructo-1kinase (PFK) activity was assayed by radiometric methods (Sola-Penna et al. 2002). Briefly, the assays were performed at $37^{\circ} \mathrm{C}$ in a reaction medium containing $50 \mathrm{mM}$ Tris- $\mathrm{HCl}$ (pH 7.4), $5 \mathrm{mM}\left(\mathrm{NH}_{4}\right)_{2} \mathrm{SO}_{4}, 5 \mathrm{mM}$ $\mathrm{MgCl}_{2}, 1 \mathrm{mM}\left[\gamma_{-}{ }^{32} \mathrm{P}\right]$ ATP $\left(4 \mu \mathrm{Ci} \cdot \mu \mathrm{mol}^{-1}\right)$, and $1 \mathrm{mM}$ fructose-6-phosphate. After different intervals, $0.4 \mathrm{~mL}$ aliquots were withdrawn and added to $1 \mathrm{~mL}$ of activated charcoal suspension $(250 \mathrm{~g} / \mathrm{L})$ containing $0.1 \mathrm{~N} \mathrm{HCl}$ and $0.5 \mathrm{M}$ mannitol. The material was centrifuged at $1.500 \mathrm{~g}$ for $10 \mathrm{~min}$, and an aliquot of the supernatant was counted in a liquid scintillation counter to evaluate the amount of [1- $\left.{ }^{32} \mathrm{P}\right]$ fructose-1,6-bisphosphate formed. Activity rate was calculated by the linear regression of the amount of $\left[1-{ }^{32} \mathrm{P}\right]$ fructose-1,6-bisphosphate formed during the linear phase of the reaction as a function of reaction time. Quadruplicates were performed for all samples and blanks were obtained in the absence of fructose-6phosphate.

\section{MiCROSCOPY}

The different cell line and fresh lymphocytes $\left(5 \times 10^{5}\right.$ cells/ $\mathrm{mL}$ ) were incubated with different concentrations of OSEME for $24 \mathrm{~h}$, centrifuged, washed and finally suspended in PBS. The morphological features of treated cells were assessed by the May-Grunwald-Giemsa's method. After fixation, structural cellular alterations were evaluated by optical microscopy. Images were acquired digitally (Veiga et al. 2005, Meira et al. 2005).

\section{Kinetic Calculations and Statistics}

Kinetics parameters were calculated by non-linear regression as described previously (Meira et al. 2005) using the Sigma Plot/SigmaStat integrated software packages (Systat, CA, USA). The OSEME dose that induces half of maximal decrease on cells viability $\left(I D_{50}\right)$, was calculated through the equation:

$$
V C=\frac{C_{0} \cdot I D_{50}}{I D_{50}+[\mathrm{OSEME}]}
$$

where $V C$ is the number of viable cell at a given dose of OSEME ([OSEME]) and $C_{0}$ is the number of viable cells in the absence of OSEME. The incubation time to achieve half of the maximal inhibition $\left(t_{0.5}\right)$ was calculated through the equation:

$$
t_{0.5}=\frac{\ln (0.5)}{-k}
$$


where $k$ is the rate constant calculated through equation:

$$
V C=C_{i} \cdot e^{-k t}
$$

where $V C$ is the number of viable cells at a given incubation time $(t)$ and $C_{i}$ is the number of viable cells before incubation.

Student's $t$-test or one-tailed ANOVA were used to determine significance between means, considering $P<0.05$ as statistical significant.

\section{RESULTS}

The parameter used to evaluate cell viability was the permeability to trypan blue dye. Results are presented as the number of non-permeable cells immediately after OSEME treatment or after a 24 hours incubation of treated cells. As demonstrated in Figure 1 OSEME promoted a dose-dependent decrease in the viability in all cell types. However, the magnitude of the inhibitory effect varied according with cell type. $\left(I D_{50}\right)$ determinations (Table I) demonstrate that OSEME was more effective in inhibiting HL-60 cells. The other tumoral cell lines K562, K562-Lucena 1 and MCF-7 were moderately sensitive to OSEME, while non-tumoral cells (3T3-L1 and fresh human lymphocytes) were relatively resistant ( $I D_{50}$ higher than $100 \mu \mathrm{g} / \mathrm{mL}$ ). These effects were also dependent on the time of incubation in the presence of OSEME. As a representative experiment, the effects of OSEME on the viability of HL-60 cells are presented in Figure 2A where it can be seen that cell viability decreases as the dose of OSEME increases. On the other hand, HL-60 incubated in the absence of OSEME grown normally (Fig. 2A, inset). From these experiments, we calculated the time to reach half of the maximal effect $\left(t_{0.5}\right)$ in the presence of different OSEME doses. This parameter decreases as the dose of OSEME increases (Table II), revealing a classical dose- and time-dependent effect. Figure 2B shows the profile of time-dependence when a $300 \mu \mathrm{g} / \mathrm{mL}$ dose of OSEME was used in viability assays using HL-60, K562 and K562-Lucena 1 cells. The calculated $t_{0.5}$ for these experiments, $(7.0 \pm 0.7$, $6.9 \pm 0.6$ and $7.0 \pm 0.8$, for HL60, K562 and K562Lucena 1 , respectively) were not significantly different $(P>0.05$, ANOVA $)$.

OSEME promoted alterations on cell morphology, size and shape, as microscopically observed in Giemsa-
TABLE I

Effect of OSEME extracts on cell viability $\left(I D_{50}\right)$.

\begin{tabular}{c|c|c}
\hline Cell line & $C_{0}\left(\times 10^{4} / \mathrm{ml}\right)$ & $\left(I D_{50}\right)(\mu \mathrm{g} / \mathrm{ml})$ \\
\hline HL-60 & $125.0 \pm 18.3$ & $9.3 \pm 0.8^{\mathrm{a}}$ \\
\hline K562 & $80.0 \pm 9.4$ & $33.9 \pm 4.3^{\mathrm{b}}$ \\
\hline K562- Lucena 1 & $58.0 \pm 7.3$ & $55.0 \pm 6.1^{\mathrm{b}}$ \\
\hline MCF-7 & $85.0 \pm 8.9$ & $48.8 \pm 5.7^{\mathrm{b}}$ \\
\hline 3T3-L1 & $88.7 \pm 9.9$ & $127.0 \pm 14.3^{\mathrm{c}}$ \\
\hline $\begin{array}{c}\text { Fresh human } \\
\text { lymphocytes }\end{array}$ & $84.4 \pm 9.4$ & $141.2 \pm 15.4^{\mathrm{c}}$ \\
\hline
\end{tabular}

Calculations were performed as indicated under Material and Methods using the experiments shown in Figure 1. $\left(I D_{50}\right)$ values with different indexes $(\mathrm{a}, \mathrm{b}$ or $\mathrm{c})$ were statistically different $(P<0.05$, Student's $t$-test).

TABLE II

Incubation time to achieve half of the maximal inhibition $\left(t_{0.5}\right)$ after treatment of mammalian cells (HL-60) with OSEME extracts.

\begin{tabular}{c|c}
\hline $\begin{array}{c}\text { Babassu extract dose } \\
(\mu \mathrm{g} / \mathrm{ml})\end{array}$ & $t_{0.5}$ (hour) \\
\hline 150 & $8.6 \pm 0.7^{\mathrm{a}}$ \\
\hline 300 & $7.0 \pm 0.7^{\mathrm{a}}$ \\
\hline 600 & $3.5 \pm 0.4^{\mathrm{b}}$ \\
\hline 1200 & $2.5 \pm 0.3^{\mathrm{c}}$ \\
\hline 1500 & $1.2 \pm 0.1^{\mathrm{d}}$ \\
\hline 2000 & $0.4 \pm 0.1^{\mathrm{f}}$ \\
\hline
\end{tabular}

Calculations were performed as indicated under material and methods using the experiments shown in Figure 2A. $t_{0.5}$ values with different indexes (a, b or c) were statistically different $(P<0.05)$, Student's $t$-test.

stained preparations of cells treated with a $1200 \mu \mathrm{g} / \mathrm{mL}$ dose of OSEME (Fig. 3). After treatment with the extract for 24 hours, cells become smaller and rounded, and presented a marked nuclear condensation. Treatment with ethanol did not promote significant alterations in animal or human cells.

In order to evaluate the effects of OSEME on the cellular metabolism, we measured the activity of PFK in HL-60 cells incubated with $300 \mu \mathrm{g} / \mathrm{mL}$ OSEME for 24 hours (Fig. 4). These cells were chosen because of their higher sensibility to the inhibitory effects of OSEME $\left(I D_{50}=9.3 \pm 0.8 \mu \mathrm{g} / \mathrm{mL}\right)$. Curiously, in comparison with ethanol-treated controls, OSEME-treated cells presented a stimulated PFK activity. However, PFK activity 


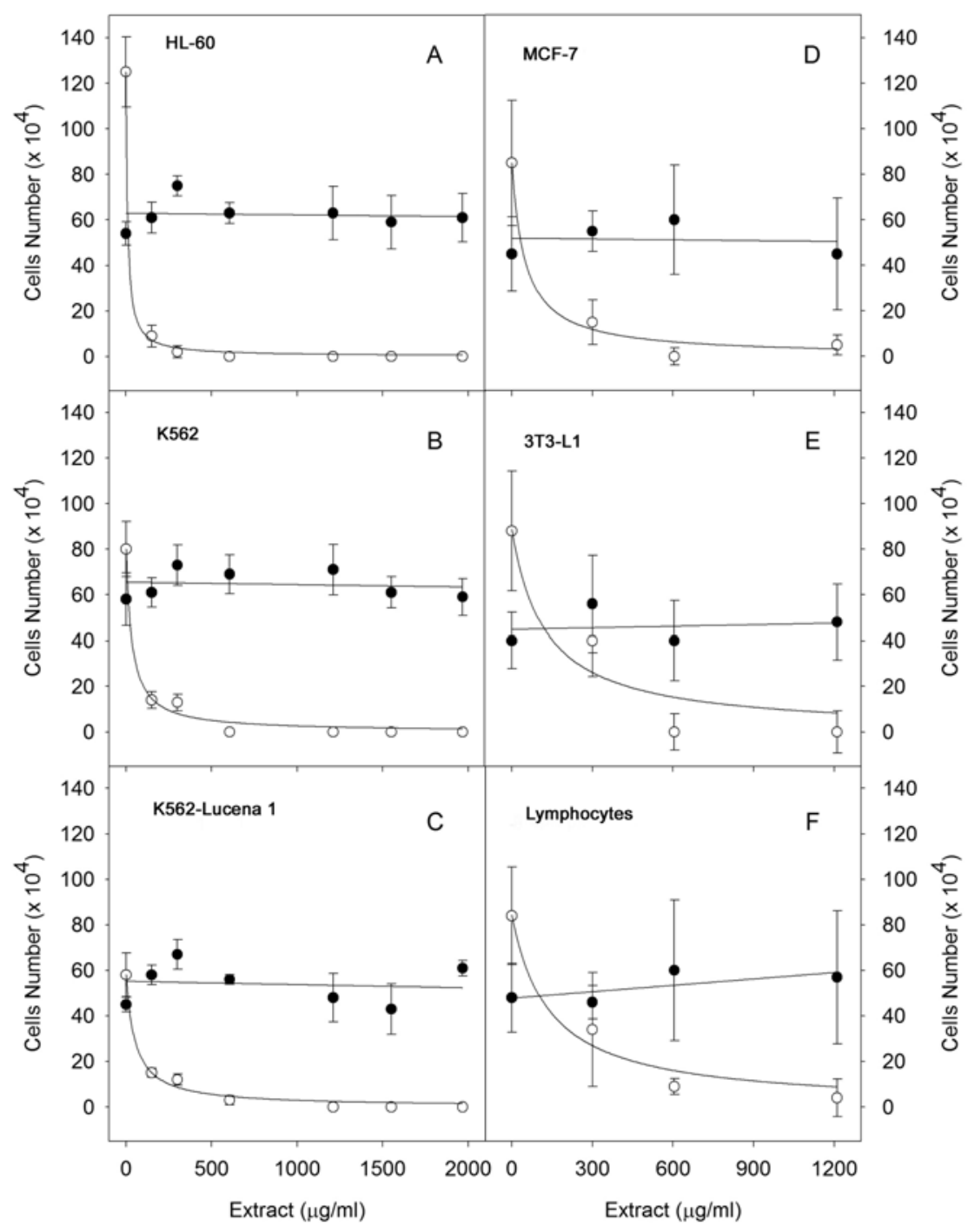

Fig. 1 - Dose-response of OSEME on the viability of different cell lines. Viability assay was performed evaluating the permeability of the cells to the trypan blue dye as described under Materials and Methods. Results are expressed as the number of non-permeable cells to the dye immediately (filled circles) or 24 hours (open circles) after addition of the concentration of OSEME indicated on the abscissa. Panel A: HL-60; B: K562; C: K562-Lucena 1; D: MCF7; E: 3T3- L1; and F: fresh human lymphocytes. Plotted values are mean \pm standard errors of 9 independent experiments. Lines are the results of the non-linear regression fitting equation (1) to the experimental data.

of OSEME-treated cells did not differ from that observed in cells that were not exposed to any treatment, suggesting that exposure to ethanol was probably the cause of enzyme inhibition.

\section{DISCUSSION}

In the current anti-cancer therapy, around $60 \%$ of the currently used drugs are derived in one way or another from natural sources, including plants, marine organisms and microorganisms (Newman et al. 2003, Cragg et al. 2005). In addition, plant-derived compounds and semisynthetic analogs have been used in combination with other chemotherapeutics for the treatment of a variety of cancers, including leukaemias, lymphomas, advanced testicular cancer, breast and lung cancers, and Kaposi's sarcoma (Cragg and Newman 2005). The search for new drugs able to overcome resistance mechanisms is of great interest for cancer therapy (Fernandes et al. 2006). 

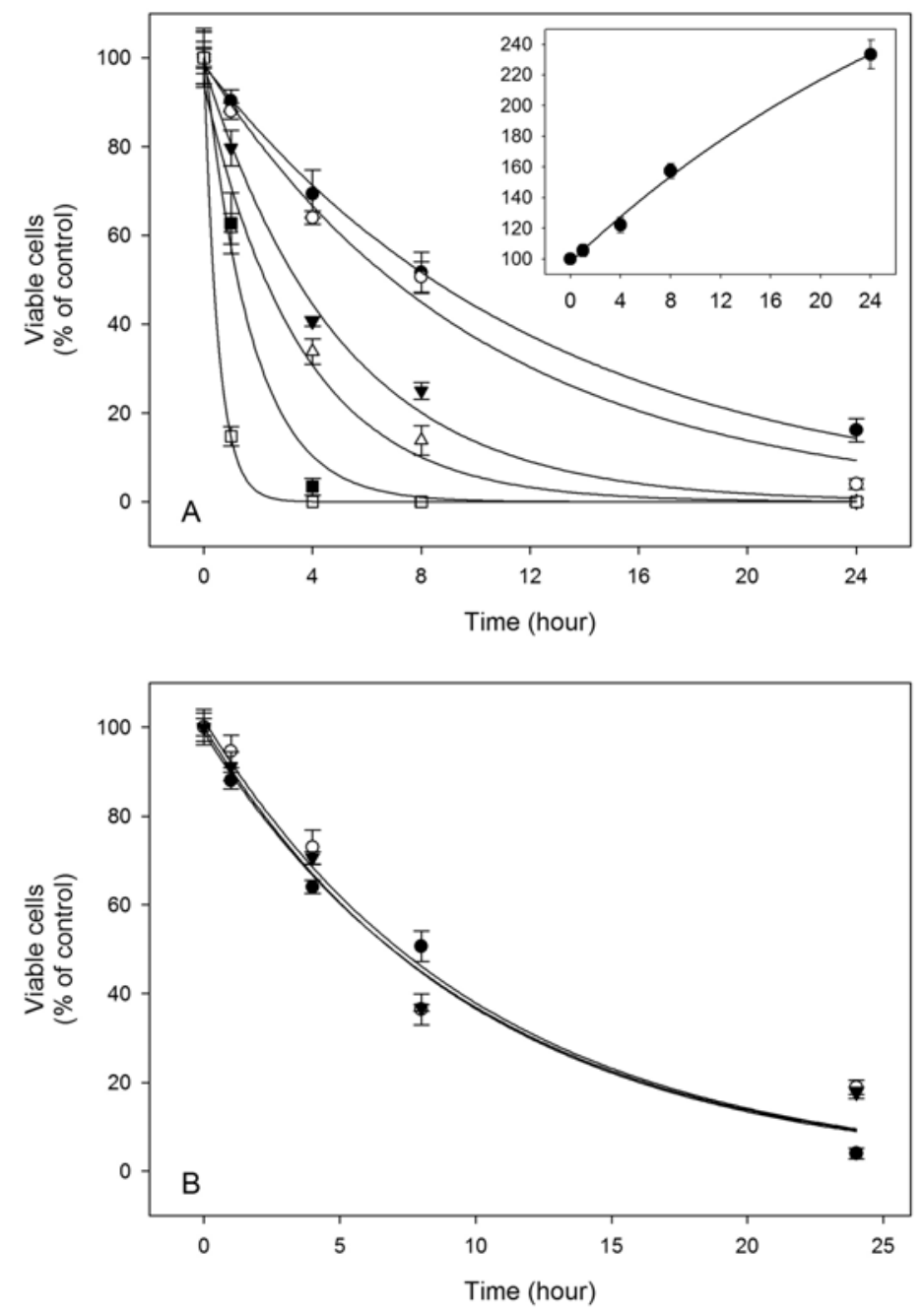

Fig. 2 - Time course of OSEME effects on cell viability. Results are expressed as the percentage of nonpermeable cells measured at the intervals indicated on the abscissa. Panel A: HL-60 cells treated with 150 (filled circles), 300 (open circles), 600 (filled down triangles), 1200 (open triangles), 1500 (filled squares) and $2000 \mu \mathrm{g} / \mathrm{mL}$ OSEME (open squares). Plotted values are mean \pm standard errors of 9 independent experiments. Lines are the results of the non-linear regression fitting equation (3) to the experimental data. Inset: control experiment in the absence of OSEME. Panel B: effects of $300 \mu \mathrm{g} / \mathrm{mL}$ OSEME on HL-60 (filled circles), K562 (open circles) and K562-Lucena 1 (filled down triangles). Plotted values are mean \pm standard errors of 9 independent experiments. Lines are the results of the non-linear regression fitting equation (3) to the experimental data.

Although the chemotherapeutic treatment of leukaemia has been dramatically improved due to newly discovered drugs, the rate of complete remission in most leukaemia patients is still not satisfactory. Additionally, the phenotype of multidrug resistance (MDR) represents the major cause of chemotherapy failure (Kartner et al. 1985, Pastan and Gottesman 1987, Ferte 2000).
In this regard, it is worthwhile to mention that the MDR cell line used in this study, K562-Lucena 1, was affected in the same extent as its non-resistant counterpart K562. This is indicative that OSEME can overcome the MDR phenotype. Additionally, the cytotoxic effects of OSEME are less prominent in non-tumor cells, indicating a potential selectivity for tumoral cells. This 


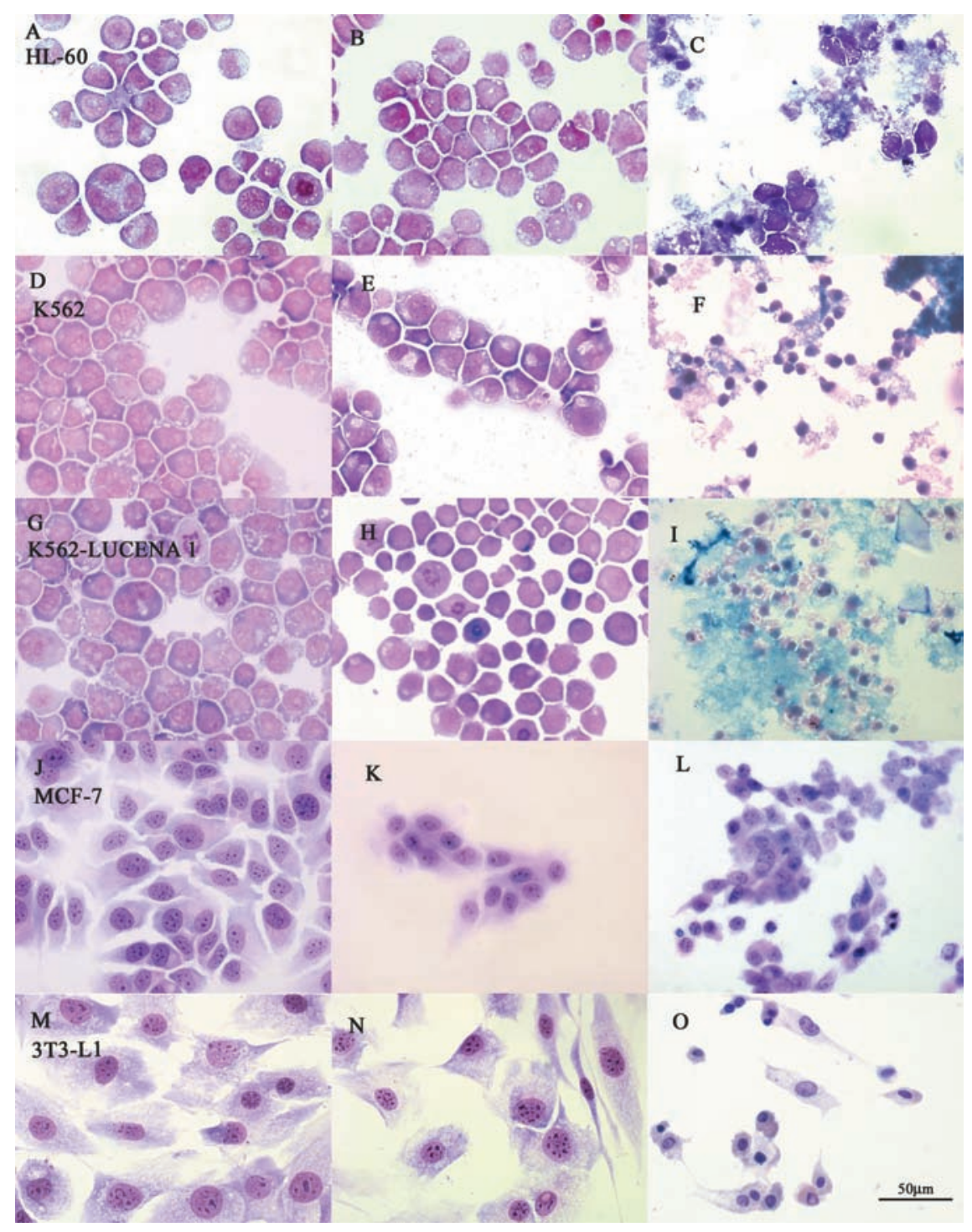

Fig. 3 - Giemsa-staining of mammalian cells in the absence and in the presence of ethanol $1.20 \%$ or $1200 \mu \mathrm{g} / \mathrm{mL}$ of OSEME. Cells were cultured and stained as described under Materials and Methods. Panels A, B and C: HL-60 cells control, $1.20 \%$ ethanol and $1200 \mu \mathrm{g} / \mathrm{mL}$ of OSEME, respectively; panels D, E and F: K562 cells control, 1.20\% ethanol and $1200 \mu \mathrm{g} / \mathrm{mL}$ of OSEME, respectively; panels $\mathrm{G}, \mathrm{H}$ and I: K562-Lucena 1 cells control, $1.20 \%$ ethanol and $1200 \mu \mathrm{g} / \mathrm{mL}$ of OSEME, respectively; panels J, K and L: MCF-7 cells control, $1.20 \%$ ethanol and $1200 \mu \mathrm{g} / \mathrm{mL}$ of OSEME, respectively; panels $\mathrm{M}, \mathrm{N}$ and O: 3 T3-L1 cells control, $1.20 \%$ ethanol and $1200 \mu \mathrm{g} / \mathrm{mL}$ of OSEME, respectively. Scale bars $=50 \mu \mathrm{m}$.

becomes clear after comparison of the OSEME $I D_{50}$ calculated from the dose-response curves presented in Figure 1. For example, $\left(I D_{50}\right)$ on leukaemic cell line HL-60 is approximately 15 times smaller than the value obtained with fresh human lymphocytes. This difference is less pronounced in the other tumoral cells ( $\sim 3$-times), although it is still highly significant. The inhibitory effect occurs rapidly, as 1 hour after incubation, a significant reduction in cell viability can be observed for all doses of OSEME tested (Fig. 2, $P<0.05$, Student's $t$-test).

Cancer cells present alterations on energetic metabolism to supply the increased demand of ATP and biosynthetic precursors to sustain their augmented cell cycle (El-Bacha and Sola-Penna 2002). These cells are char- 


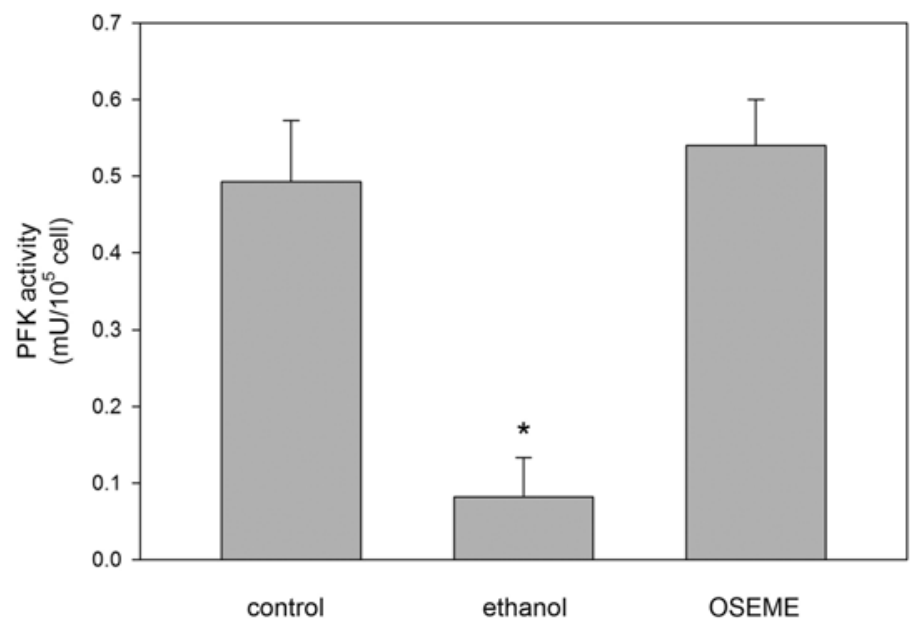

Fig. 4 - PFK activity of HL-60 cells incubated in the absence or in the presence of ethanol or $300 \mu \mathrm{g} / \mathrm{mL}$ OSEME. PFK activity was accessed as described under Materials and Methods. Values are mean \pm standard errors of 4 independent experiments. ${ }^{*} P<0.05$ compared to control or to $300 \mu \mathrm{g} / \mathrm{mL}$ OSEME.

acterized by a high glycolytic rate, which is not inhibited by the presence of oxygen such as in normal mammalian cells (Gatenby and Gillies 2004). The dependence on the glycolytic flux as energy source is higher in aggressive metastatic tumors than in less proliferative neoplasic cells (Kubota 2001). It is frequently observed that tumor malignancy is accompanied by an increase in glucose consumption, lactate production and media acidification (Ashrafian 2006). Classical anticancer agents, such as paclitaxel and vinca alkaloids, inhibit glycolysis in cancer cells (Vertessy et al. 1997, Glass-Marmor and Beitner 1999). Recently, we have demonstrated that clotrimazole decreases human breast cancer cells viability by inhibiting the key glycolytic enzyme, 6-phosphofructo1-kinase (PFK) (Meira et al. 2005). These effects occur in parallel to alterations on cell morphology that includes reduction on cell volume, formation of rounded cells and a marked nuclear condensation, which was associated to induction of apoptosis (Vermes et al. 2000, Meira et al. 2005). In the present work, OSEME promoted similar cellular alterations. This effect is also seen on the MDR cell line K562-Lucena 1, supporting the evidences that OSEME can overcome the MDR phenotype of tumoral cells. However, $300 \mu \mathrm{g} / \mathrm{mL}$ of OSEME did not inhibit PFK activity of HL-60 cells after 24 hours incubation. Since calculated PFK activity was corrected by the number of non-permeable cells, we may suggest that this phenomenon is due to the fact that the remain- ing cells present an enhanced metabolic activity in order to overcome the toxic effects of OSEME. Similar results have been reported elsewhere (Penso and Beitner 2002, 2003, Meira et al. 2005, Leite et al. 2007). We also tried to perform MTT experiments; however OSEME reduced MTT reagent, disguising the results (data not shown).

The presence of bioactive constituents such as, triterpenes, tannins, sugars, saponins and steroid compounds (Bandeira et al. 1986, Garcia et al. 1995) could be correlated to the pharmacological properties of babassu. Silva and Parente isolated from the mesocarp of fruits of Orbignya phalerata a polysaccharide with anti-inflammatory and immunomodulatory properties (Silva and Parente 2001) and our research group described the antioxidant activity of OSEME (Silva et al. 2005). All these properties reinforce the OSEME cytotoxicity, which additionally may present a multi-target action that is desirable in a chemotherapeutical.

The purpose of the present work is to assess in vitro anti-tumor properties of crude ethanol extract against a panel of selected tumoral and non-tumoral cells. In conclusion, results show that ethanol extract from epicarp/mesocarp of babassu exhibit cytotoxic activities against preferentially tumoral cells, comparing with nontumoral cells, and provide preliminary evidences for the presence of one or more ethanol-soluble constituents with anti-tumor properties. Other studies are necessary to identify the active component(s), to elucidate the 
mechanisms to support the use of babassu as a source of new anti-tumor drugs.

\section{ACKNOWLEDGMENTS}

We thank Dr. Marcio Rodrigues for critical reading of the manuscript and Dr. Ken Boylan for language review. This work was supported by Financiadora de Estudos e Projetos (FINEP), Conselho Nacional de Desenvolvimento Científico e Tecnológico (CNPq), Fundação Carlos Chagas Filho de Amparo à Pesquisa no Estado do Rio de Janeiro (FAPERJ), Fundação José Bonifácio (FUJB), Fundação Ary Franzino/Fundação Educacional Charles Darwin (FAF/FECD/ONCO), Projetos de Pesquisa para o Sistema Único de Saúde (PPSUS/FAPERJ) and Programa de Apoio a Núcleos de Excelência (PRONEX).

\section{RESUMO}

Substâncias derivadas de plantas têm sido usadas como importante fonte de agentes antineoplásicos. O mesocarpo do babaçu é popularmente usado no Brasil como suplemento alimentar e na medicina popular para o tratamento de várias afecções, tais como: inflamações, cólicas menstruais e leucemia. A partir do epicarpo/mesocarpo do babaçu Orbignya speciosa (Mart.) Barb. Rodr. [Arecaceae (Palmae)] foi preparado um extrato etanólico, denominado OSEME, o qual foi incubado com as seguintes linhagens humanas leucêmicas: HL-60, K562 e a sua derivada resistente a múltiplas drogas, K562-Lucena 1; além destas, foram testadas a linhagem humana de câncer de mama, MCF-7; a linhagem de fibroblastos de camundongo, 3T3-L1 e linfócitos humanos de sangue periférico. OSEME promoveu diminuição da viabilidade em todas as linhagens celulares testadas de maneira dose-dependente. Este efeito foi mais pronunciado sobre as linhagens celulares tumorais quando comparado às não tumorais, o que foi revelado pela dose de OSEME capaz de promover metade do efeito máximo $\left(I D_{50}\right)$. A diminuição da viabilidade foi acompanhada por danos sobre a morfologia celular com pronunciada condensação citoplasmática e nuclear. Curiosamente, quando a linhagem HL-60 foi tratada com OSEME, foi detectado um aumento de 6,6 vezes da atividade da enzima 6-fosfofrutoquinase, quando comparado ao grupo controle (células tratadas com o veículo etanol). Esses resultados sugerem que OSEME pode ser uma promissora fonte de novos agentes antineoplásicos.

Palavras-chave: agentes antitumorais, extrato etanólico, Orbignya speciosa.

\section{REFERENCES}

Ashrafian H. 2006. Cancer's sweet tooth: the Janus effect of glucose metabolism in tumorigenesis. Lancet 367 : $618-621$

AzEVEDo AP ET AL. 2007. Anti-thrombotic effect of chronic oral treatment with Orbignya phalerata Mart. J Ethnopharmacol 111: 155-159.

Bandeira MAM, Matos MEO, Matos FJA And MaiA MBS. 1986. Contribuição ao estudo químico do coco babaçu. Rev Bras Farmacognosia 1: 27-28.

Baruque Ga, Bitencourt Ma, Pasquine R, CasTElo-Branco MTL, Llerena JR. JC AND RUMJANEK VM. 2005. Apoptosis and expression of anti- and pro-apoptotic proteins in peripheral blood mononuclear cells of Fanconi anaemia patients: a study of 73 cases. Eur J Haematol 75: 384-390.

Batista CP, Torres OJ, Matias JE, Moreira AT, Colman D, lima JH, Macri MM, Rauen JR. RJ, Ferreira LM AND Freitas AC. 2006. Effect of water extract of Orbignya phalerata (babassu) in the gastric healing in rats: morfologic and tensiometric study. Acta Cir Bras 21: 26-32.

Caetano N, Saraiva A, Pereira R, Carvalho D, Pimentel MCB And Maia MBS. 2002. Determinação de atividade antimicrobiana de extratos de plantas de uso popular como antiflamatório. Rev Bras Farmacognosia 12: $132-135$.

Cragg GM and Newman DJ. 2005. Plants as a source of anti-cancer agents. J Ethnopharmacol 100: 72-79.

Cragg GM, Kingston DGi and Newman DJ (Eds). 2005. Anticancer Agents from Natural Products. Brunner-Routledge Psychology Press, Taylor \& Francis Group, Boca Raton, FL.

El-BACHA TP AND Sola-Penna M. 2002. Alterações no metabolismo de células neoplásicas. In: DA POIAN AT, Carvalho-Alves PC (Eds), Hormônios e Metabolismo: Integração e correlações clínicas, Editora Atheneu, São Paulo SP, Brazil, p. 319-332.

EMMERICH FG AND LUENGO CA. 1996. Babassu charcoal: a sulphurless, renewable, thermo-reducing feedstock for steelmaking. Biomass Bioenergy 10: 41-44.

FERGUSON LR AND PhilpotT M. 2007. Cancer prevention by dietary bioactive components that target the immune response. Curr Cancer Drug Targ 7: 459-464.

Fernandes J, Weinlich R, CAstilho RO, AmaranteMendes GP And Gattass CR. 2006. Pomolic acid may overcome multidrug resistance mediated by overexpression of anti-apoptotic Bcl-2 proteins. Cancer Letters, $1-6$. 
FERTE J. 2000. Analysis of the tangled relationships between P-glycoprotein-mediated multidrug resistance and the lipid phase of the cell membrane. Eur J Biochem 267: 277-294.

FREShNEY RI. 1994. Culture of Animal Cells: A Manual of Basic Technique. In: Wiley-Liss Inc. Publications, ed.

Gaitan E, COOKSEY RC, LEgAn J, Lindsay RH, INGBAR SH AND Medeiros-Neto G. 1994. Antithyroid effects in vivo and in vitro of babassu and mandioca: a staple food in goiter areas of Brazil. Eur J Endocrinol 131(2): 138-144.

Garcia S, Heizein H, Hubbuch C, Martinez R, De VRIES X AND MOYNA P. 1995. Triterpene methyl ethers from palmae epicuticular waxes. Phytochemistry 39: 1381-1382.

Gatenby RA AND Gillies RJ. 2004. Why cancers have high aerobic glycolysis? Nat Rev Cancer 4: 891-899.

Glass-Marmor L And Beitner R. 1999. Taxol (paclitaxel) induces a detachment of phosphofructokinase from cytoskeleton of melanoma cells and decreases the levels of glucose 1,6-bisphosphate, fructose 1,6-bisphosphate and ATP. Eur J Pharmacol 370: 195-199.

Holandino C, Veiga VF, Rodrigues mL, Morales MM, Capella MAM and Alviano CS. 2001. Direct current decreases cell viability but not $\mathrm{P}$-glycoprotein expression and function in human multidrug resistant leukaemic cell. Biolectromagnetics 22: 470-478.

Kartner N, Evernden-Porelle D, Bradley G AND LING V. 1985. Detection of Pglycoprotein in multidrugresistant cell lines by monoclonal antibodies. Nature 269: 820-823.

Kubota K. 2001. From tumor biology to clinical Pet: a review of positron emission tomography (PET) in oncology. Ann Nucl Med 15: 471-486.

Leite TC, DA Silva D, Coelho RG, Zancan P AND SOLA-PENNA M. 2007. Lactate favours the dissociation of skeletal muscle 6-phosphofructo-1-kinase tetramers down-regulating the enzyme and muscle glycolysis. Biochem J 408: 123-130.

Maia RC, WAgner K, CABRAl RH And RumJaneK VM. 1996. Heparin reverses Rhodamine 123 extrusion by multidrug resistant cells. Cancer Letters 106: 101-108.

Martins NL, Malafaia O, Ribas-Filho JM, Heibel M, BAldez RN, VAsconcelos PR, Moreira H, Mazza M, NASSif PA AND WALlbach TZ. 2006. Healing process in cutaneous surgical wounds in rats under the influence of Orbignya phalerata aqueous extract. Acta Cir Bras 21: 66-75.
Meira DD, Marinho-Carvalho MM, Teixeira CA, Veiga VF, da Poian AT, Holandino C, DE FreiTAS MS AND Sola-PEnNa M. 2005. Clotrimazole decreases human breast cancer cells viability through alterations in cytoskeleton-associated glycolytic enzymes. Mol Gen Metab 84: 354-362.

Newman DJ, Cragg GM and Snader KM. 2003. Natural products as sources of new drugs over the period 19812002. J Nat Prod 66: 1022-1037.

PASTAN I AND GotTesman M. 1987. Multiple-drug resistance in human cancer. N Engl J Med 316: 1388-1393.

PATTERSON JR MK. 1979. Measurement of growth and viability of cells in culture. Cell Culture. In: JАКОВY WB AND PAStAn IH (Eds), Methods in Enzymology Academic Press, New York 58: 141-152.

Penso J And Beitner R. 2002. Clotrimazole decreases glycolysis and the viability of lung carcinoma and colon adenocarcinoma cells. Eur J Pharmacol. 451(3): 227235.

PEnso J AND BeItNer R. 2003. Lithium detaches hexokinase from mitochondria and inhibits proliferation of B16 melanoma cells. Mol Gen Metab 78: 74-78.

Silva BP AND PARENTE JP. 2001. An anti-inflammatory and immunomodulatory polysaccharide from Orbignya phalerata. Fitoterapia 72: 887-893.

SILVA CG ET AL. 2005. Evaluation of antioxidant activity of Brazilian plants. Pharmacol Res 52: 229-233.

Sola-Penna M, Santos AC, Serejo F, Alves GG, ElBacha T, FAber-Barata J, Pereira MF, dA Poian AT AND SORENSON M. 2002. A radioassay for phosphofructokinase-1 activity in cell extracts and purified enzyme. J Biochem Biophys Meth 50: 129-140.

Veiga VF, Nimrichter L, Teixeira CA, Morales MM, Alviano CS, Rodrigues ML and HolanDINO C. 2005. Exposure of human leukemic cells to direct electric current: generation of toxic compounds inducing cell death by different mechanisms. Cell Biochem Biophys 42: 61-74.

VERMES I, HAANEN C AND REUTELINGSPERGER C. 2000. Flow cytometry of apoptotic cell death. J Immunol Methods 243: 167-190.

Vertessy BG, Kovacs J, LöW P, LehotzKy A, MolNÁR A, OROSZ F AND Ovadi J. 1997. Characterization of microtubule-phosphofructokinase complex: specific effects of MgATP and vinblastine. Biochemistry 36: 2051-2062. 